OPEN ACCESS

Edited by:

Aixin Yan,

The University of Hong Kong,

China

Reviewed by:

Atte Von Wright,

University of Eastern Finland, Finland

Renko De Vries,

Wageningen University, Netherlands

*Correspondence:

Ming Sun

m98sun@mail.hzau.edu.cn

Specialty section:

This article was submitted to Antimicrobials, Resistance and

Chemotherapy,

a section of the journal

Frontiers in Microbiology

Received: 14 April 2016

Accepted: 04 July 2016

Published: 19 July 2016

Citation:

Xin B, Zheng J, Liu H, Li J, Ruan L, Peng D, Sajid M and Sun M (2016)

Thusin, a Novel Two-Component Lantibiotic with Potent Antimicrobial Activity against Several Gram-Positive Pathogens. Front. Microbiol. 7:1115.

doi: 10.3389/fmicb.2016.01115

\section{Thusin, a Novel Two-Component Lantibiotic with Potent Antimicrobial Activity against Several Gram-Positive Pathogens}

\author{
Bingyue Xin, Jinshui Zheng, Hualin Liu, Junhua Li, Lifang Ruan, Donghai Peng, \\ Muhammad Sajid and Ming Sun *
}

State Key Laboratory of Agricultural Microbiology, College of Life Science and Technology, Huazhong Agricultural University, Wuhan, China

Due to the rapidly increasing prevalence of multidrug-resistant bacterial strains, the need for new antimicrobial drugs to treat infections has become urgent. Bacteriocins, which are antimicrobial peptides of bacterial origin, are considered potential alternatives to conventional antibiotics and have attracted widespread attention in recent years. Among these bacteriocins, lantibiotics, especially two-component lantibiotics, exhibit potent antimicrobial activity against some clinically relevant Gram-positive pathogens and have potential applications in the pharmaceutical industry. In this study, we characterized a novel two-component lantibiotic termed thusin that consists of Ths $\alpha$, Ths $\beta$, and Ths $\beta$ ' (mutation of Ths $\beta, A 14 G$ ) and that was isolated from a $B$. thuringiensis strain BGSC 4BT1. Ths $\alpha$ and Ths $\beta$ (or Ths $\beta$ ') exhibit optimal antimicrobial activity at a 1:1 ratio and act sequentially to affect target cells, and they are all highly thermostable $\left(100^{\circ} \mathrm{C}\right.$ for $\left.30 \mathrm{~min}\right)$ and $\mathrm{pH}$ tolerant ( $\mathrm{pH} 2.0$ to 9.0). Thusin shows remarkable efficacy against all tested Gram-positive bacteria and greater activities than two known lantibiotics thuricin 4A-4 and ticin A4, and one antibiotic vancomycin against various bacterial pathogens (Bacillus cereus, Listeria monocytogenes, Staphylococcus aureus (MRSA), Staphylococcus sciuri, Enterococcus faecalis, and Streptococcus pneumoniae). Moreover, thusin is also able to inhibit the outgrowth of $B$. cereus spores. The potent antimicrobial activity of thusin against some Gram-positive pathogens indicates that it has potential for the development of new drugs.

Keywords: two-peptide lantibiotics, Bacillus thuringiensis BGSC 4BT1, thusin, vancomycin, Gram-positive pathogens

\section{INTRODUCTION}

The introduction of antibiotics for the treatment of infections is the most significant scientific achievement of the twentieth century with regard to reducing human morbidity and mortality (Andersson and Hughes, 2010; Brown and Wright, 2016). Unfortunately, the extensive use of antibiotics has resulted in the development of multidrug-resistant pathogens, and mining new antimicrobials is considered to be an effective solution to this problem (Cotter et al., 2013). To date, the investigated alternatives to traditional antibiotics include plant-derived compounds, 
bacteriophages, RNA-based therapeutics, probiotics, and antimicrobial peptides of different origins (Shanahan, 2010; Burrowes et al., 2011; Kole et al., 2012; Li et al., 2012; Savoia, 2012). Antimicrobial peptides of bacterial origin, known as bacteriocins, are ribosomally synthesized peptides that exert a bactericidal or bacteriostatic effect on other bacteria either of the same species (narrow spectrum) or across genera (broad spectrum) and have been regarded as a promising source of antimicrobials (Cotter et al., 2005, 2013). They include posttranslationally modified bacteriocins and unmodified or cyclic bacteriocins (Cotter et al., 2013).

Lanthipeptides (lantibiotics) are small peptides that undergo extensive posttranslational modification and are considered the best-characterized bacteriocins (Schnell et al., 1988; Willey and Van der Donk, 2007). The posttranslational modifications include the dehydration of Ser and Thr residues to yield dehydroalanine (Dha) and dehydrobutyrine (Dhb) residues, respectively. This dehydration is followed by the stereospecific intramolecular addition of a Cys residue onto the dehydroamino acids to form a lanthionine (Lan) or methyllanthionine (MeLan) bridge. Many lantibiotics exhibit broad-spectrum antimicrobial activity against clinically relevant Gram-positive pathogens, including multidrug-resistant pathogens, and are a promising class of new antibacterial agents (Severina et al., 1998; Cotter et al., 2005, 2013; Dischinger et al., 2014; Sandiford, 2014).

A special subclass of two-component lantibiotics consists of two peptide systems that are formed from two precursor peptides posttranslationally modified to form two distinct active products (Garneau et al., 2002). The individual peptides have little or no antimicrobial activity; however, equimolar concentrations of the two peptides act in synergy to exhibit significantly higher activity (Morgan et al., 2005). At present, a number of two-component lantibiotics have been described, some of which may have applications in the pharmaceutical and food industries (Navaratna et al., 1998; Ryan et al., 1999; Holo et al., 2001; Hyink et al., 2005; Yonezawa and Kuramitsu, 2005; McClerren et al., 2006; Begley et al., 2009; Sawa et al., 2012). For example, the best-studied two-component lantibiotic, lacticin 3147, consists of $\operatorname{Ltn} \alpha$ and $\operatorname{Ltn} \beta$ and exhibits potent antimicrobial activity against a number of pathogenic Gram-positive bacteria, such as methicillin-resistant Staphylococcus aureus (MRSA), vancomycin-resistant Enterococcus faecalis (VRE), penicillinresistant Pneumococcus (PRP), Propionibacterium acnes, Streptococcus mutans, Clostridium difficile, and Mycobacteria (Galvin et al., 1999; Morgan et al., 2005; Rea et al., 2007; Carroll et al., 2010; Dobson et al., 2011; Piper et al., 2012). Lacticin 3147 also substantially attenuated Strep. mutans biofilm formation (Dobson et al., 2011) and prevented the systemic spread of Staph. aureus in mice (Piper et al., 2012). Although there are a number of two-component lantibiotics have been described, the properties of them are different, such as the antimicrobial activity and stability (Willey and Van der Donk, 2007; Knerr and Van der Donk, 2012). Therefore, it's necessary to mine more antimicrobials of that type to satisfy people's demands.

In our previous research, we demonstrated that the $B$. cereus group is an excellent reservoir of novel lanthipeptides, and four types of two-component lanthipeptide gene clusters were predicted in the strains of this group (Xin et al., 2015b). In this study, we identified and characterized one type of the two-component lantibiotics, the thusin gene cluster from a $B$. thuringiensis strain BGSC 4BT1. The two components, Ths $\alpha$ and Ths $\beta$ (or Ths $\beta$ '), acted synergistically against most of the tested Gram-positive bacteria and were able to inhibit the outgrowth of Bacillus cereus spores. In addition, comparison of the antimicrobial activities of thusin, thuricin 4A-4, ticin A4, and vancomycin against six species of Gram-positive bacterial pathogens suggested that thusin may be a promising therapeutic agent.

\section{MATERIALS AND METHODS}

\section{Strains and Culture Conditions}

The B. thuringiensis strain BGSC 4BT1 was kindly provided by the Bacillus Genetic Stock Center (BGSC) and propagated on

TABLE 1 | The antimicrobial activity of Ths $\alpha$, Ths $\beta$, and Thusin.

\begin{tabular}{lccc}
\hline Indicator strain $^{\mathrm{a}}$ & ${\text { MIC }(\mu \mathrm{M})^{\mathrm{b}}}$ & & \\
& Ths $\alpha$ & Ths $\beta$ & Thusin
\end{tabular}

\section{GRAM-NEGATIVE BACTERIA}

Sphingobacterium Pri1

Pseudomonas putida Pri3

Pseudomonas psychrophila Pri5

Escherichia coli OP50 (Xin et al., 2015a)

E. coli BL21 (Xin et al., 2015a)

Erwinia herbicola LS005(Xin et al., 2015a)

Klebsiella pneumoniae CMCC 46117

Salmonella paratyphi CMCC 50093

Salmonella paratyphi CMCC 50094

Shigella dysenteriae CMCC 51105

Pseudomonas aeruginosa ATCC 27853

\section{GRAM-POSITIVE BACTERIA}

Bacillus cereus ATCC 14579

Bacillus thuringiensis BMB171 (Xin et al., 2015a)

Bacillus pumilus SCG I (Xin et al., 2015a)

Bacillus subtilis Bsn5 (Deng et al., 2011)

Bacillus amyloliquefaciens X1 (Xin et al., 2015a)

Listeria monocytogenes LM201 (Wu et al., 2015)

Listeria monocytogenes LM605

Staphylococcus aureus CMCC 26003

Staphylococcus aureus ATCC 43300

Staphylococcus aureus MRSA

Staphylococcus sciuri Bom1

Enterococcus faecalis ATCC 29212

Streptococcus pneumoniae ATCC 49619

$\begin{array}{lll}- & - & - \\ - & - & - \\ - & - & - \\ - & - & - \\ - & - & - \\ - & - & - \\ - & - & - \\ - & - & - \\ - & - & - \\ - & - & - \\ - & - & -\end{array}$

${ }^{a}$ ATCC, American Type Culture Collection. CMCC, China Medical Culture Collection. See references for the source of the marked strains. Unmarked strains were isolated by our group

${ }^{b}$ The highest concentrations of Ths $\alpha$, Ths $\beta$, and Thusin were all $100 \mu \mathrm{M}$. The minus sign denotes no activity against the indicator strains, even at the highest concentrations of the indicated peptides. 
Luria-Bertani (LB) agar plates at $28^{\circ} \mathrm{C}$. The other strains, which served as indicator strains, are listed in Table $\mathbf{1 .}$

\section{The Prediction of the Lanthipeptide}

\section{Biosynthetic Gene Cluster and Analysis of the Promoter and Terminator in the Thusin Gene Cluster}

The bacteriocin biosynthetic gene clusters were predicted using

BAGEL 3.0 (Van Heel et al., 2013). The putative promoter and terminator in the thusin gene cluster were detected using the Softberry BPROM and Find Term software programs, respectively.

\section{Purification of Antibacterial Peptides}

B. thuringiensis BGSC 4BT1 was grown in Luria-Bertani (LB) broth at $28^{\circ} \mathrm{C}$. At the early stationary phase $\left(\mathrm{OD}_{600} \approx 3.0\right)$, the cells were removed by centrifugation at $12,000 \mathrm{rpm}$ for $10 \mathrm{~min}$. The concentration of active substances was measured using

A

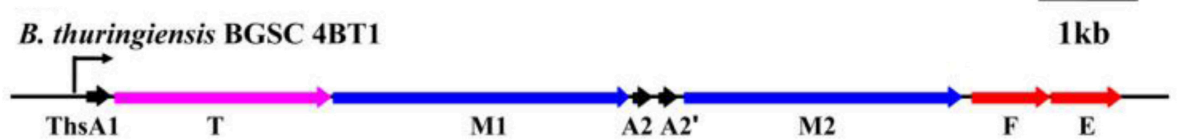

B

LchA1

\section{$\sqrt{\mathrm{B}} \sqrt{\mathrm{B}} \mathrm{D}$}

32

HalA1

ITLSTCAILSKPLGNNGYLCTVTKECMPSCN

28

P1wA1

CAWYNISCRLGNKGAYCTLTVECMPSECN

29

BhtA1

KCKWWNISCDLGNNGHVCTLSHECQVSCN

32

SmbA1

IGTTVVNSTFSIVLGNKGYICTVTVECMRNCQ

33

ThsA1

IGTTVVNSTFS IVLGNKGYICTVTVECMRNCSK

INTWNTTATSTSI I ISETFGNKGKVCTYTVECVNNCRG

38

LtnA1

П

SacA1

CSTNTFSLSDYWGNNGAWCTLTHECMAWCK

CSTNTFSLSDYWGNKGNWCTATHECMSWCK

30

Mrs

CT---F--TLPGGGGV--CTLTSECI--C

30

Leader peptide

ThsA1: VLDVIKNRKKIEEKLELPEILLEEVEEHSAMGG

C

\begin{tabular}{|c|c|c|}
\hline \multicolumn{3}{|c|}{ 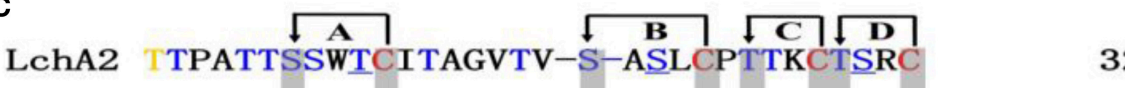 } \\
\hline Ha1A2 & TTWPCATVGV---S-VALCPTTKCTSQC & \\
\hline 1wA2 & SGIPCTIGAAVAAS-IAVCPTTKCSKRCGKRKK & \\
\hline SmbA2 & STPACAI-GVVGITVAVTGISTACTSRCINK & \\
\hline BhtA2 & STPACAI-GVVGITVAVTGISTACTSRCINK & \\
\hline LtnA2 & TTPA---TPA-ISILSAYIS-TNTCPTTKCTRAC & \\
\hline SacA2 & GTPL-ALLGGAATGVIGYIS-NQTCPTTACTRAC & \\
\hline ThsA2 & GTPA--ITTA-IS-AI IAATAQSPCPTSACSKSCNK & \\
\hline ThsA2' & GTPA--ITTA-IS-AIIGATAQSPCPTSACSKSCNK & \\
\hline er & peptide & \\
\hline AsA2: & MLKEEKLEKITGLIPESELEEHLSGESSGA & \\
\hline hsA2': & : M-KEQKLEKITGLIPESELEEHLSGESSGA & \\
\hline
\end{tabular}

FIGURE 1 | Thusin biosynthetic gene cluster in B. thuringiensis BGSC 4BT1 and amino acid sequence alignment of three precursor peptides with class II lantibiotic propeptides. (A) Line diagram of the thusin gene cluster in B. thuringiensis BGSC 4BT1. Bent arrow represents the promoter of the thusin gene cluster. Amino acid sequence alignment of ThsA1 (B), ThsA2 and ThsA2' (C) with other reported class II lantibiotic propeptides. Cys residues are marked in red. Ser/Thr residues that are dehydrated are shown in blue, and non-dehydrated residues are underlined. Ser/Thr residues, post-translationally modified to D-Ala/Obu, are shown in green/yellow. Thioether and disulfide bonds are marked with arrows and are boxed in gray. Two of the six Ser/Thr residues are not dehydrated in the mature peptides of ThsA2 and ThsA2', but these residues could not be conclusively identified based on the current data; these six amino acids are displayed in violet. Thioether bridging rings in the Lch $\alpha$ and $L c h \beta$ peptides are indicated with the capital letters $A, B, C$, and D. The probable protease cleavage site sequences (GG) are shown in red. 
Amberlite XAD-7HP (Sigma, St Louis, MO, USA) as described previously (Xin et al., 2015a). Briefly, the cell-free supernatant fluid (5 L) was shaken with $500 \mathrm{~g}$ of Amberlite XAD-7HP (Sigma, St. Louis, MO, USA) for $12 \mathrm{~h}$ at $4^{\circ} \mathrm{C}$. The resin was sequentially washed with $2 \mathrm{~L}$ of distilled water and $1 \mathrm{~L}$ of $30 \%(\mathrm{vol} / \mathrm{vol})$ ethanol. The active substances were eluted with $500 \mathrm{~mL}$ of $80 \%$ ( $\mathrm{vol} / \mathrm{vol}$ ) ethanol, $\mathrm{pH} 2.0$, and the eluate was collected and lyophilized into a powder. The generated powder was dissolved in $5 \mathrm{~mL}$ of acetonitrile $50 \%(\mathrm{vol} / \mathrm{vol})$ followed by centrifugation. The resulting supernatant is referred to as antimicrobial crude extract (CE). The CE was analyzed using the Waters 1525 Breeze system. The solvents were (A) HPLC-grade water with $0.1 \%$ trifluoroacetic acid (TFA) and (B) acetonitrile, and these solvents were applied using the following gradient: $20-60 \%$ B from 0 to $30 \mathrm{~min}$ at a flow rate of $1.0 \mathrm{~mL} / \mathrm{min}$. The resulting quantity of Ths $\alpha$, Ths $\beta$, and Ths $\beta$ ' was quantified by weighing and the compounds were reconstituted in distilled water $(0.5 \mathrm{mg} / \mathrm{mL})$.

Vancomycin hydrochloride was purchased from Sigma with purity greater than $90 \%$ and was reconstituted in distilled water $(0.1 \mathrm{mM})$. Purification of thuricin 4A-4 and ticin A4 was carried out as described previously (Xin et al., 2015a,b). The purities of thuricin $4 \mathrm{~A}-4$, ticin A4, Ths $\alpha$, Ths $\beta$, and Ths $\beta$ ' were determined by HPLC using the above described procedure, and the values all exceeded $90 \%$.

\section{The Optimal Peptide Ratio for the Antimicrobial Effect of Thusin}

The activated $B$. thuringiensis BMB171 cultures were subcultured in $5 \mathrm{~mL}$ of LB medium $\left(5 \times 10^{5} \mathrm{cfu} / \mathrm{mL}\right)$ that contained varying amounts of Ths $\alpha$ and Ths $\beta$ (or Ths $\beta^{\prime}$ ) at $28^{\circ} \mathrm{C}$ with agitation at $220 \mathrm{rpm}$ for $5 \mathrm{~h}$. Bacterial growth was evaluated by measuring the culture $\mathrm{OD}_{600}$.

\section{Antimicrobial Activity Assay and Determination of Minimal Inhibitory Concentration (MIC) Values}

The antimicrobial activity of the fermental supernatant of strain BGSC 4BT1 and the eluate in HPLC analysis were assessed using the agar well diffusion method as described previously (Xin et al., 2015b). The minimal inhibitory concentration (MIC) was assessed using the DIN-58940-8 microdilution method (Assadian et al., 2011). Briefly, the test strains were cultivated overnight and diluted to reach $5 \times 10^{5} \mathrm{cfu} / \mathrm{mL}$. Tests were performed

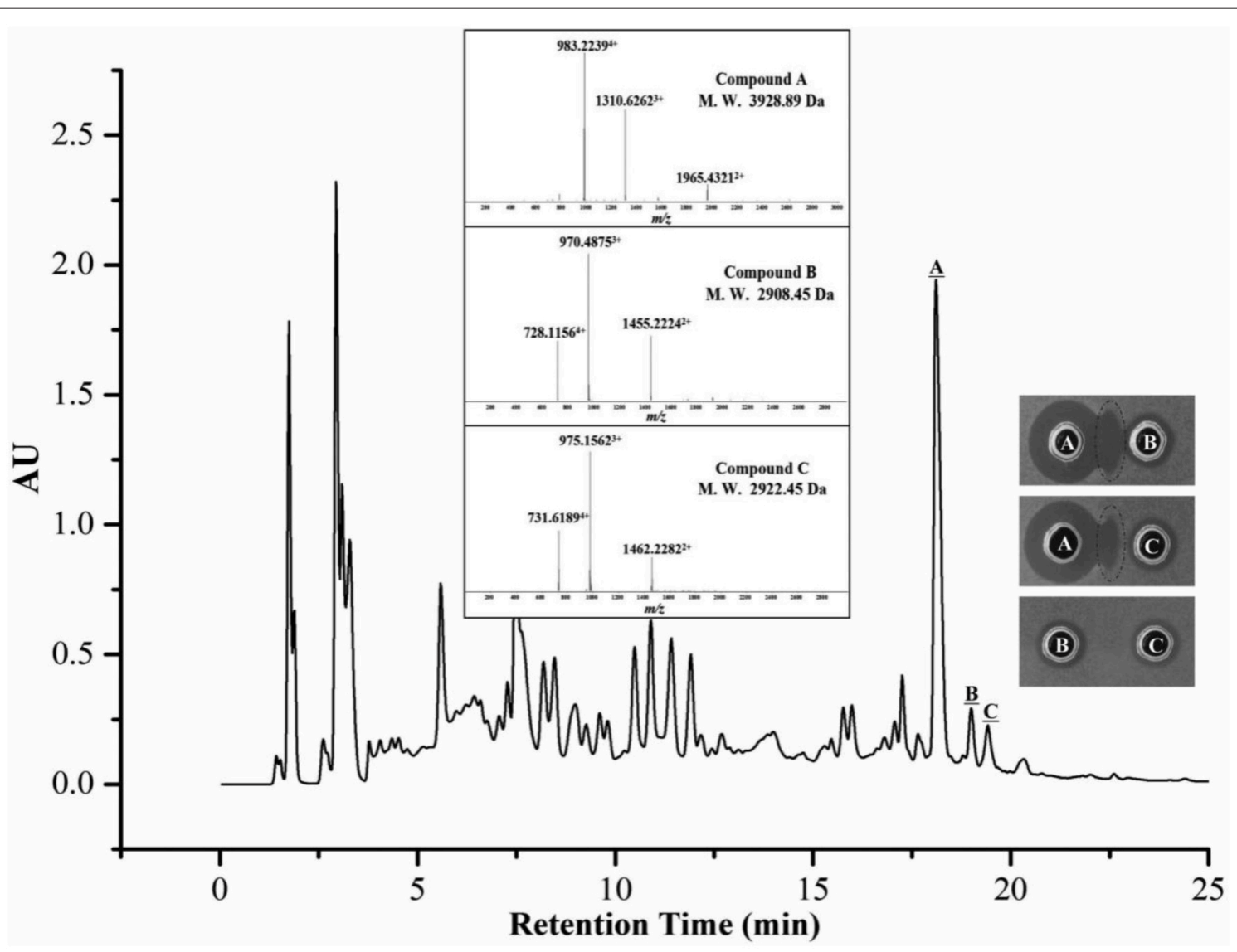

FIGURE 2 | LC-MS analysis of a crude extract from a B. thuringiensis BGSC 4BT1 culture supernatant. Only three fractions (A, B, and C) corresponding to three peaks with retention times of $18.1,19.0$, and 19.4 min were active against $B$. thuringiensis BMB171. The complementary activity was observed between fractions $\mathrm{A}$ and $\mathrm{B}$ as well as between fractions $\mathrm{A}$ and $\mathrm{C}$ but not between fractions $\mathrm{B}$ and $\mathrm{C}$. 
A
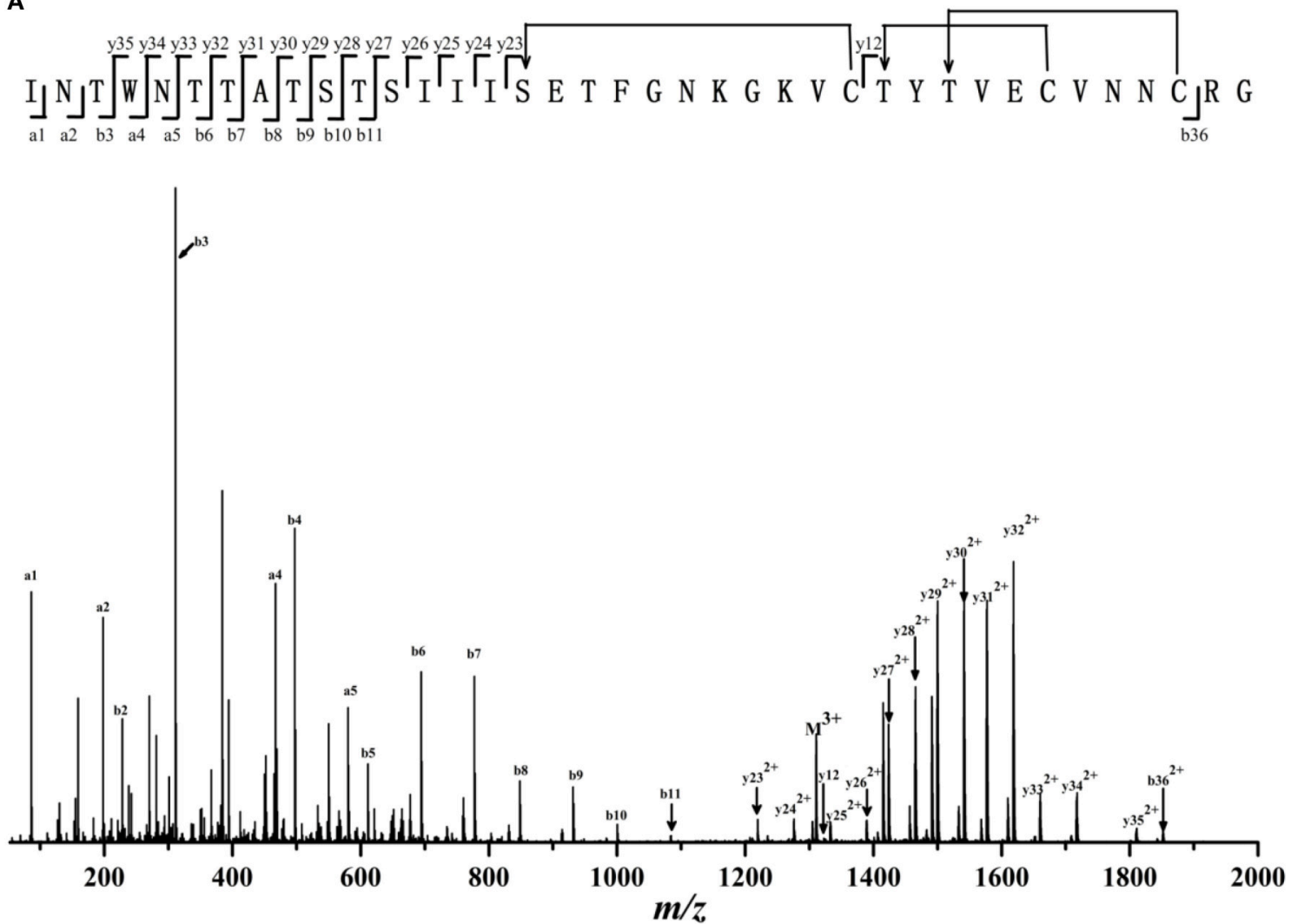

B

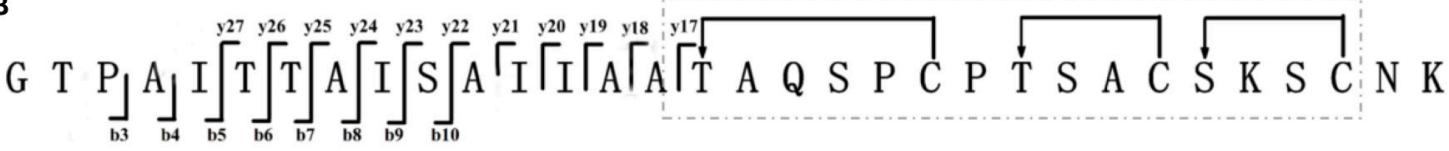

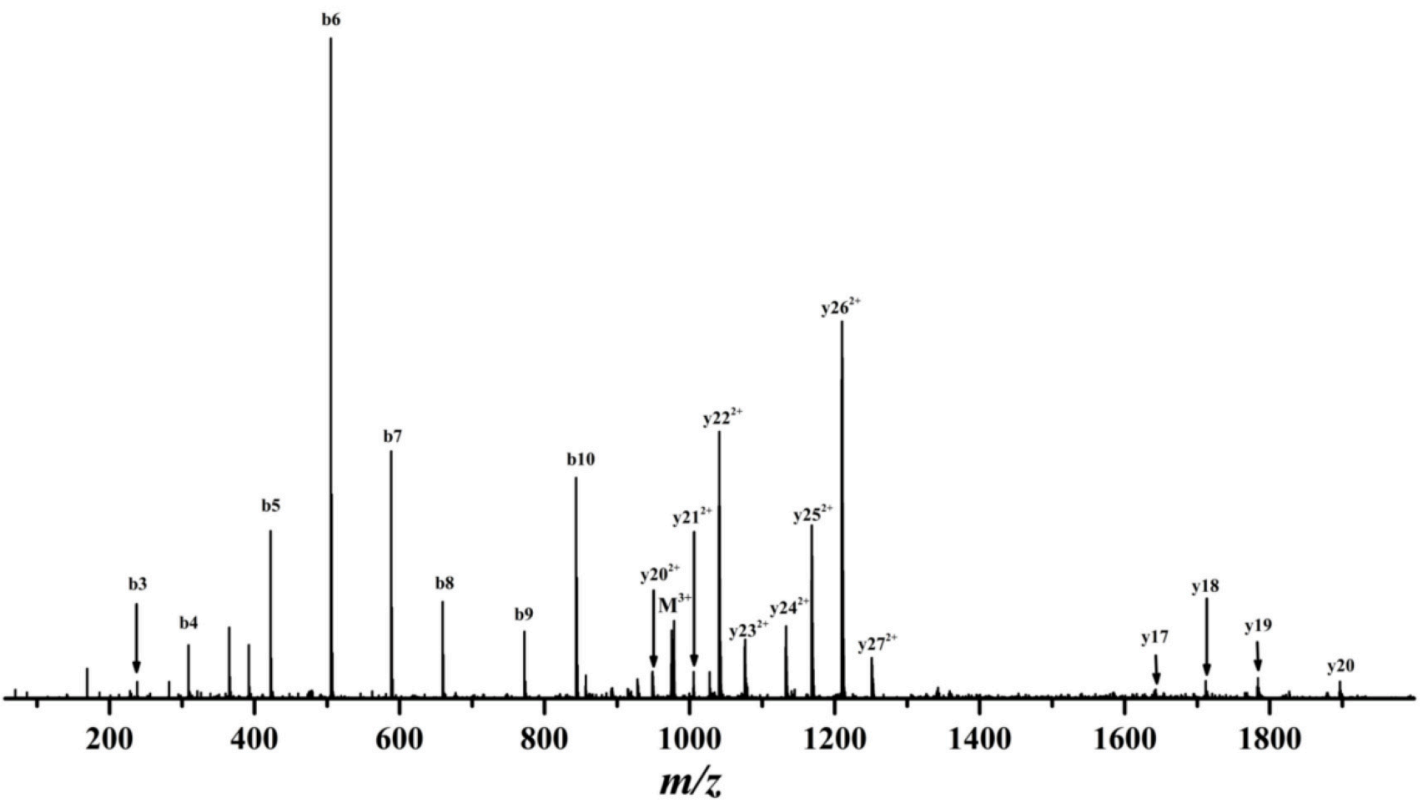

FIGURE 3 | ESI-MS/MS spectra and proposed primary structure of Ths $\alpha$ (A) and Ths $\beta$ (B). Fragment ions are indicated. The putative thioether bridging rings of Ths $\alpha$ and Ths $\beta$ are shown. Two of the six Ser/Thr residues are not dehydrated in mature peptides of ThsA2, but these residues could not be conclusively identified based on the current data; these six amino acids are shown in gray. The putative thioether bridging rings of Ths $\beta$ in the dashed boxes were presumed based on the reported class II lantibiotics which had been identified their structures. 
using 96-well microtiter plates. Each well was filled with $100 \mu \mathrm{L}$ of serial two-fold dilutions of the antimicrobials and $100 \mu \mathrm{L}$ of the inoculum and incubated at $37^{\circ} \mathrm{C}$ for $24 \mathrm{~h}$. All experiments were performed in triplicate. The MIC was defined as the lowest concentration of samples that could inhibit visible growth of the tested strains.

\section{Structural Analysis of Ths $\alpha$, Ths $\beta$, and Ths $\beta$ '}

LC-MS and LC-MS/MS were used to analyze the structures of Ths $\alpha$, Ths $\beta$, and Ths $\beta$ ' using the Agilent 6540 ultra-highdefinition (UHD) accurate-mass quadrupole time of flight (Q-TOF) LC-MS system. The MS operating conditions were as follows: capillary voltage, $3500 \mathrm{~V}$; flow rate of drying gas, $9 \mathrm{~L} / \mathrm{min}$; nebulizer pressure, $35 \mathrm{lb} / \mathrm{in}^{2}$ gauge; and temperature, $350^{\circ} \mathrm{C}$. The scanning range of the Q-TOF was $m / z 100$ to 3000 . MS/MS analysis was performed on the doubly and tripled charged ions of each peptide. The target ion fragmented by adding a voltage varied from 20 to $80 \mathrm{~V}$.

\section{Sensitivity of Antimicrobial Peptides to Temperature and $\mathrm{pH}$}

To determine the sensitivities of Ths $\alpha$, Ths $\beta$, and Ths $\beta$ ' to $\mathrm{pH}$, aliquots of the bacteriocin preparations $(5 \times$ MIC) were adjusted to $\mathrm{pH} 2.0,3.0,7.0,8.0,9.0$, and 10.0 with $1 \mathrm{M} \mathrm{NaOH}$ or $1 \mathrm{M}$ $\mathrm{HCl}$ solution followed by incubation at $28^{\circ} \mathrm{C}$ for $2 \mathrm{~h}$, and the residual antimicrobial activity was measured after neutralizing the sample to $\mathrm{pH}$ 6.0. For the thermal stability assay, aliquots of the bacteriocin preparations $(5 \times \mathrm{MIC})$ were exposed to 80,100 , and $121^{\circ} \mathrm{C}$ for $30 \mathrm{~min}$ and used for an antimicrobial activity assay. B. thuringiensis BMB171 was used as the indicator strain in these two experiments.

\section{Ths $\alpha$ and Ths $\beta$ Act Sequentially to Affect the Sensitive Strain}

The $B$. thuringiensis $\mathrm{BMB} 171$ cultures $\left(\mathrm{OD}_{600} \approx 0.5\right)$ were diluted 10 -fold, and $200 \mu \mathrm{L}$ of the diluted culture was added to $1.5 \mathrm{~mL}$ Eppendorf tubes that contained Ths $\alpha$ or Ths $\beta$ (at concentrations of $0,10,30$, and $60 \mathrm{nM}$ ). The tubes were incubated at $37^{\circ} \mathrm{C}$ for $30 \mathrm{~min}$ prior to centrifugation at $12,000 \mathrm{rpm}$ for $1 \mathrm{~min}$. The supernatants were removed from each tube, and the cell pellets were washed twice with LB broth, then resuspended in $200 \mu \mathrm{L}$ of LB broth. Cells that had been treated with only Ths $\alpha$ were added to microtiter wells that contained Ths $\beta$, and cells that had been exposed to only Ths $\beta$ were added to microtiter wells that contained Ths $\alpha$ (at concentrations of $0,10,30$, and $60 \mathrm{nM}$ ). The microtiter plates were incubated at $28^{\circ} \mathrm{C}$ and monitored at hourly intervals for $5 \mathrm{~h}$. In addition, cells exposed to Ths $\alpha$ and Ths $\beta$ in combination at a ratio of 1:1 served as a control.

\section{Inhibition of Bacillus cereus Spore Outgrowth}

Germination assays were conducted as described previously (Hornstra et al., 2005) with few modifications. B. cereus ATCC14579 spores were activated by incubation at $70^{\circ} \mathrm{C}$ for $15 \mathrm{~min}$ and were then transferred into LB broth at an optical density at $600 \mathrm{~nm}$ of 0.8 . After adding different amounts of antimicrobials, the germination process was followed by monitoring the optical density at $600 \mathrm{~nm}$ every $10 \mathrm{~min}$.

\section{Nucleotide Sequence Accession Number}

The whole-genome shotgun sequencing results for $B$. thuringiensis BGSC 4BT1 have been deposited in GenBank under accession no. LILG00000000. The nucleotide sequence of the thusin gene cluster has been deposited in GenBank under accession no. KT454399.

\section{RESULTS}

\section{Characterization and Identification of One Two-Component Lanthipeptide Biosynthetic Gene Cluster in B. thuringiensis BGSC 4BT1}

Our previous research demonstrated that B. cereus group strains are a prolific source of novel lantibiotics, and four types of the two-component lanthipeptide biosynthetic gene clusters that have not yet been biochemically characterized were predicted in the strains of this group (Xin et al., 2015b). Among these clusters, one type of putative two-component lanthipeptide gene cluster can be mined from the genome sequences of $B$. thuringiensis BGSC $4 \mathrm{BD} 1$ and $4 \mathrm{BT} 1$, and we functionally verified this gene cluster in strain 4BT1. This gene cluster, $\sim 10 \mathrm{~kb}$ in length, consists of eight genes, including three structural genes (ths $A 1$, ths $A 2$, and ths $A 2^{\prime}$ ), two genes encoding a posttranslational modification enzyme (thsM1 and thsM2), two genes encoding an $\mathrm{ABC}$ transporter that could be involved in immunity (thsEF), and one gene (thsT) encoding a transporter (Figure 1A). Only one putative promoter was predicted in the upstream thsA1 gene, and no terminator was found in the DNA region of this gene cluster (Figure 1A). In addition, three putative precursor peptides are characterized by an $\mathrm{N}$ terminal leader sequence with a conserved $G(\mathrm{G} / \mathrm{A})$ cleavage site (Figures 1B,C). The amino acid sequence of ThsA1 (71

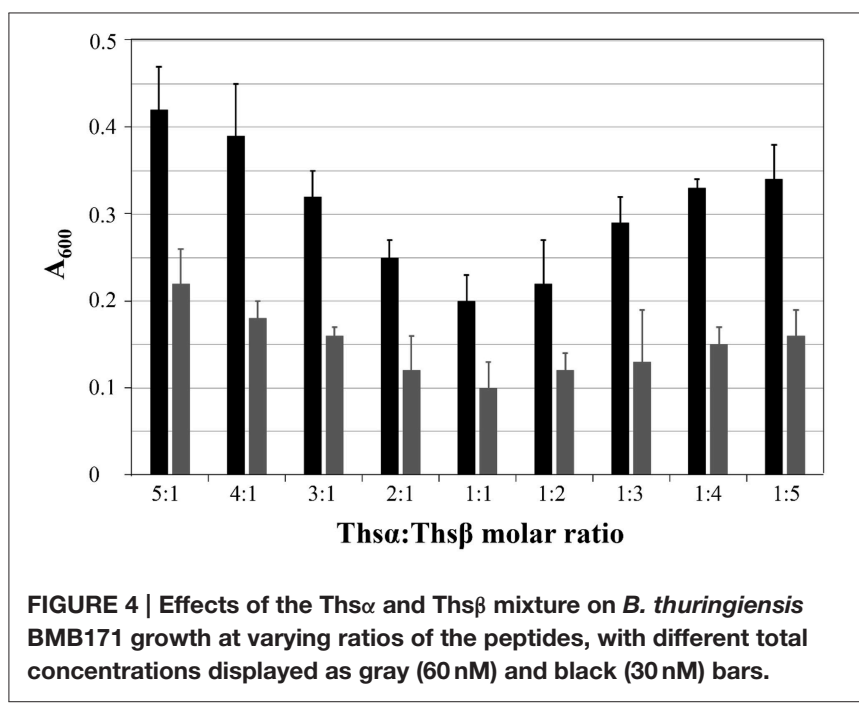


aa) shows the highest identity with LchA1 (43.8\%).(Shenkarev et al., 2010) The sequences of ThsA2 (62 aa) and ThsA2' (61 aa) are nearly identical (95\% identity), and they are most similar to that of $\mathrm{LtnA} 2$ (33.3 and $30.8 \%$, respectively) (Ryan et al., 1999).

\section{Purification and Identification of Ths $\alpha$, Ths $\beta$, and Ths $\beta$ '}

The kinetics of the antimicrobial substance production assay demonstrated that strain 4BT1 produced antimicrobials during the exponential phase (Figure S1). The antimicrobials from a $12 \mathrm{~h}$ culture of $4 \mathrm{BT} 1$ in LB medium (the exponential phase of growth) were concentrated on Amberlite XAD-7 HP resin and separated by reverse-phase HPLC (RP-HPLC). As shown in Figure 2, only three fractions corresponding to three peaks with retention times of $18.1 \mathrm{~min}, 19.0 \mathrm{~min}$ and $19.4 \mathrm{~min}$ were active against $B$. thuringiensis BMB171. Note that complementary activity was observed between fractions $\mathrm{A}$ and $\mathrm{B}$ as well as between fractions $\mathrm{A}$ and $\mathrm{C}$ but not between fractions $\mathrm{B}$ and $\mathrm{C}$. This phenomenon was similar to that observed for a previously reported two-component lantibiotic, lacticin 3147 (Ryan et al., 1999). Moreover, the LC-MS data showed that the molecular mass of fraction A was 3928.89 Da (Figure 2). The calculated molecular mass of the predicted mature peptide of ThsA1, Ths $\alpha$, was $198.74 \mathrm{Da}$ higher than the measured mass, indicating that all 11 serine and threonine residues were dehydrated. Two compounds, B and C, with molecular masses of 2908.45 Da and 2922.45 Da, were detected in fractions B and C, respectively (Figure 2). The calculated molecular masses of the predicted products of the structural genes ths 22 and ths $A 2^{\prime}$ were $3065.52 \mathrm{Da}$ and $3051.50 \mathrm{Da}$, respectively, which were each $143.07 \mathrm{Da}$ higher than the measured masses of compounds $\mathrm{C}$ and $\mathrm{B}$, indicating that eight of the ten serine or threonine residues were dehydrated.

We then used LC-MS/MS to analyze the detailed sequence information of Ths $\alpha$, Ths $\beta$, and Ths $\beta$ '. As shown in Figure 3A and Table S1, all marked fragment ions of compound A corresponded to fragments of Ths $\alpha$. No cleavage was observed from Ser16 to Cys26 or from Thr27 to Cys36, indicating the presence of an intramolecular thioether bridge (Lan and/or MeLan). The marked fragments of compound B correspond to the fragments of Ths $\beta$ ' (Figure S2 and Table S3), and those of compound $\mathrm{C}$ correspond to the fragments of Ths $\beta$ (Figure 3B and Table S2). The molecular mass difference of fragment ions b5, b6, and b7 was $83.03 \mathrm{Da}$, and that of fragment ions y22 and y23 was $71.04 \mathrm{Da}$, indicating that Thr6, Thr7, and Ser10 were dehydrated (Figure 3B and Figure S2). Four of the six residues (Ser19, Ser24, Ser27, Ser29, Thr16, and Thr23) were also dehydrated, but we could not accurately identify these residues based on the current data. In addition, no cleavage was observed from Thr16 to Cys30 (Figure 3B and Figure S2), suggesting the presence of intramolecular thioether bridges, but we could not determine the precise structure from the current data. Given the MS/MS analysis and the structural similarity (thioether bridging rings) between thusin and the reported twocomponent lantibiotics (Figures 1B,C), we proposed possible Lan and MeLan bridges in Ths $\alpha$, Ths $\beta$, and Ths $\beta$ ' (Figure 3 and Figure S2).

\section{Ths $\alpha$ and Ths $\beta$ Function Optimally at a 1:1 Ratio}

Before assessing the specific antimicrobial activity of thusin, the optimal ratio of Ths $\alpha$ to Ths $\beta$ (or Ths $\beta$ ') that maximized the

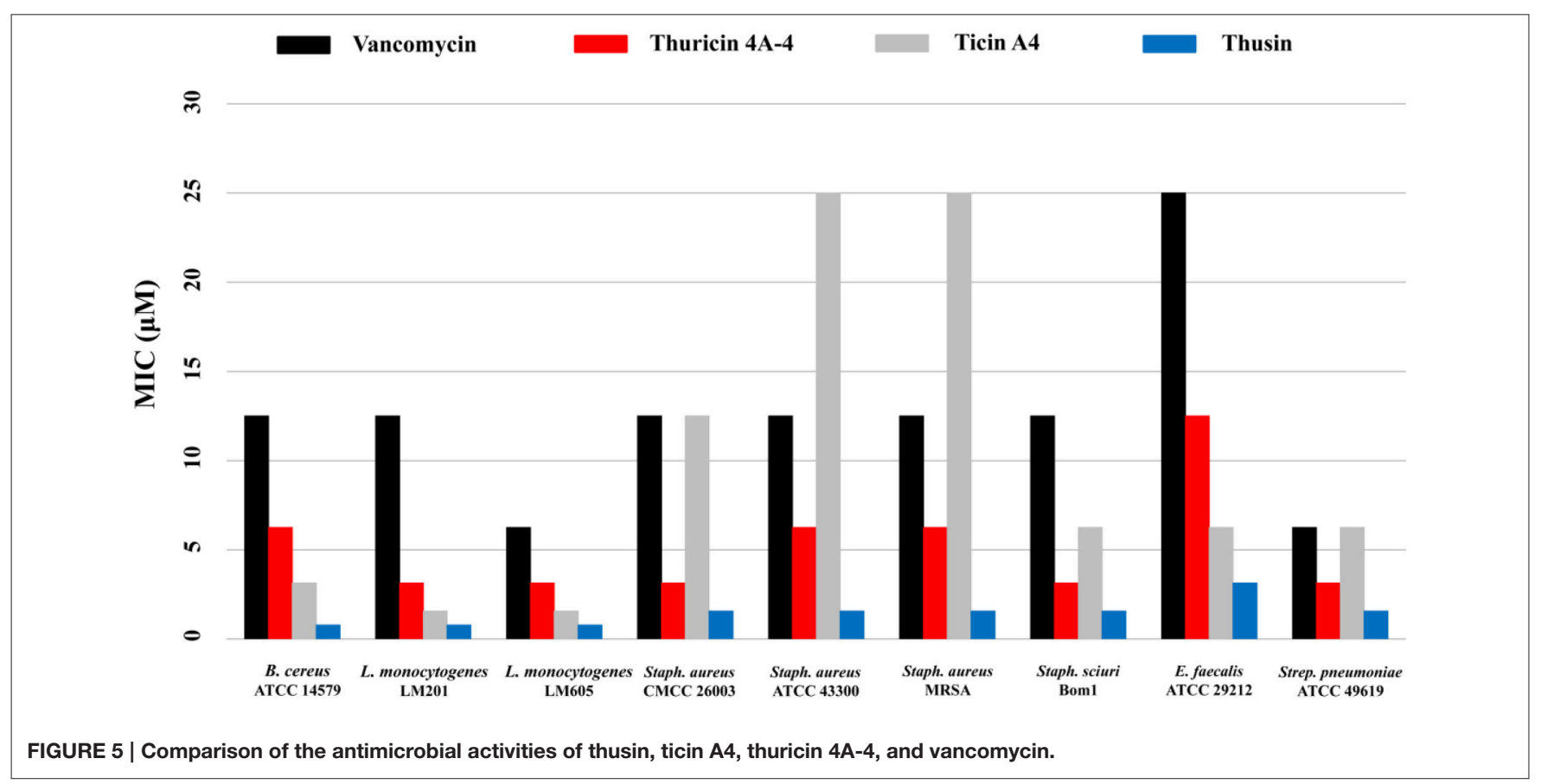


bioactivity was determined. The ability of mixtures containing various amounts of Ths $\alpha$ and Ths $\beta$ (or Ths $\beta$ ') to inhibit the growth of $B$. thuringiensis BMB171 was examined. As shown in Figure 4, thusin is active against the indicator strain $B$. thuringiensis BMB171 at nanomolar levels, and Ths $\alpha$ and Ths $\beta$ exhibit maximum activity at a 1:1 ratio. The combination of Ths $\alpha$ and Ths $\beta$ ' also showed the same result (data not shown). The optimal synergy of Ths $\alpha$ and Ths $\beta$ (or Ths $\beta$ ') at a 1:1 ratio is consistent with reports of other two-component lantibiotics, such as staphylococcin C55, plantaricin W, lacticin 3147, and haloduracin (Navaratna et al., 1998; Holo et al., 2001; Morgan et al., 2005; Oman and Van der Donk, 2009).

\section{The Antimicrobial Activity and Stability of Thusin}

The biological activities of the HPLC-purified Ths $\alpha$, Ths $\beta$, and Ths $\beta$ ' against a battery of Gram-positive and Gramnegative bacteria were measured. Ths $\alpha$, Ths $\beta$, and Ths $\beta$ ' were active against all tested Gram-positive bacteria, including B. amyloliquefaciens, B. cereus, B. thuringiensis, B. subtilis, B. pumilus, E. faecalis, L. monocytogenes, Staph. aureus, Staph. Sciuri, and Strep. pneumoniae, but not against any of the tested Gram-negative bacteria (Table 1). The antimicrobial activities of Ths $\beta$ and Ths $\beta$ ' were essentially comparable, so we only showed the data for Ths $\beta$. The Ths $\alpha$ and Ths $\beta$ mixture at a molar ratio of 1:1 had a 4- to 16 -fold increase in efficacy compared with the peptides used individually. Therefore, Ths $\alpha$ and Ths $\beta$ could synergistically inhibit Gram-positive bacteria. In addition, we also compared the antimicrobial activity of thusin, thuricin 4A-4, ticin A4, and vancomycin against six species of Gram-positive pathogens (Figure 5). The MIC determinations revealed that thusin had higher activity against all tested Gram positive bacterial pathogens than those of thuricin $4 \mathrm{~A}$ 4, ticin A4, and vancomycin. Thusin had 8-fold higher activity against L. monocytogenes LM605, Staph. aureus CMCC 26003, Staph. aureus ATCC 43300, Staph. aureus MRSA, Staph. sciuri Bom1, and E. faecalis ATCC 29212 than vancomycin. Thusin showed 16-fold higher activity against B. cereus ATCC 14579 and $L$. monocytogenes LM201 than vancomycin. In addition, thusin displayed 2-fold to 16 -fold higher activity against nine tested indicator bacteria than those of thuricin 4A-4 and ticin A4 (Figure 5). These results suggested that thusin might be more effective at treating infections caused by Grampositive pathogens than thuricin $4 \mathrm{~A}-4$, ticin $\mathrm{A} 4$ and even vancomycin.

The sensitivities of Ths $\alpha$, Ths $\beta$, and Ths $\beta$ ' to $\mathrm{pH}$ and temperature were also tested. As shown in Figure 6A, Ths $\alpha$, Ths $\beta$, and Ths $\beta$ ' were all stable under acidic conditions, but were not stable under neutral and alkaline conditions. All of the peptides totally lost their activity when they were incubated at $\mathrm{pH} 10.0$ for $2 \mathrm{~h}$. In addition, Ths $\alpha$, Ths $\beta$, and Ths $\beta^{\prime}$ all remained active after incubation at 80 and $100^{\circ} \mathrm{C}$ for $30 \mathrm{~min}$ (Figure 6B). Ths $\alpha$ retained approximately $50 \%$ of its activity when it was autoclaved at $121^{\circ} \mathrm{C}$ for $30 \mathrm{~min}$, but the residual antibacterial activities of Ths $\beta$ and Ths $\beta$ ' were greatly decreased.

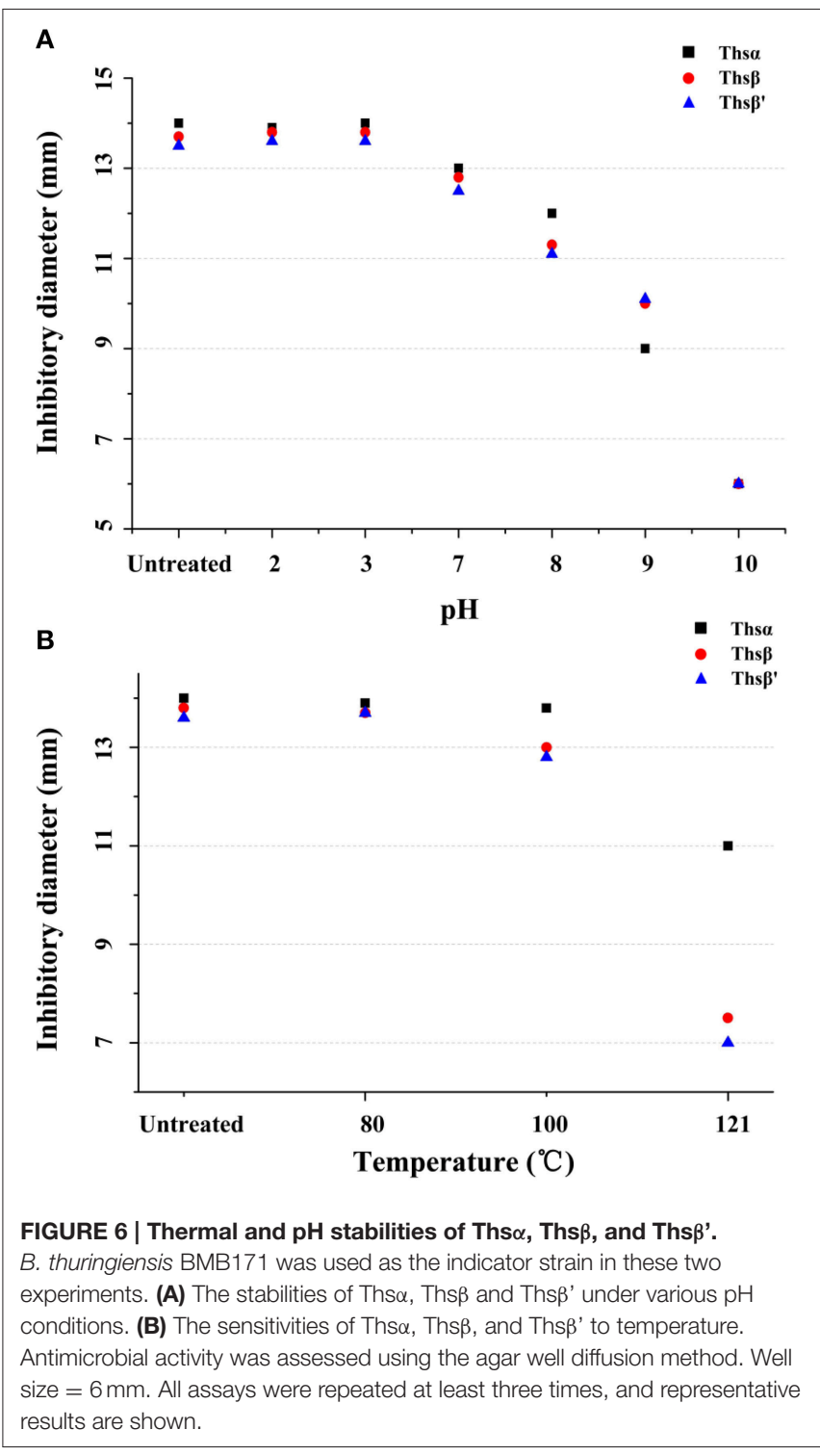

\section{Ths $\alpha$ and Ths $\beta$ Act Sequentially to Affect Sensitive Strains}

To reveal the potential roles of the individual peptides of thusin, the peptides were sequentially added and cell growth was examined. As indicated in Figure 7B, when the sensitive strains were incubated with Ths $\alpha$ prior to incubation with Ths $\beta$, cell growth was inhibited. When the cells were first exposed to Ths $\beta$ and were subsequently treated with Ths $\alpha$, growth inhibition was not observed (Figure 7C). When Ths $\alpha$ and Ths $\beta$ peptides were added in combination, growth inhibition was observed (Figure 7A).

\section{Thusin Can Inhibit the Outgrowth of Bacillus cereus Spores}

The ability of thusin to prevent spore outgrowth was assessed. The optical density of the samples at $600 \mathrm{~nm}$ indicated that 


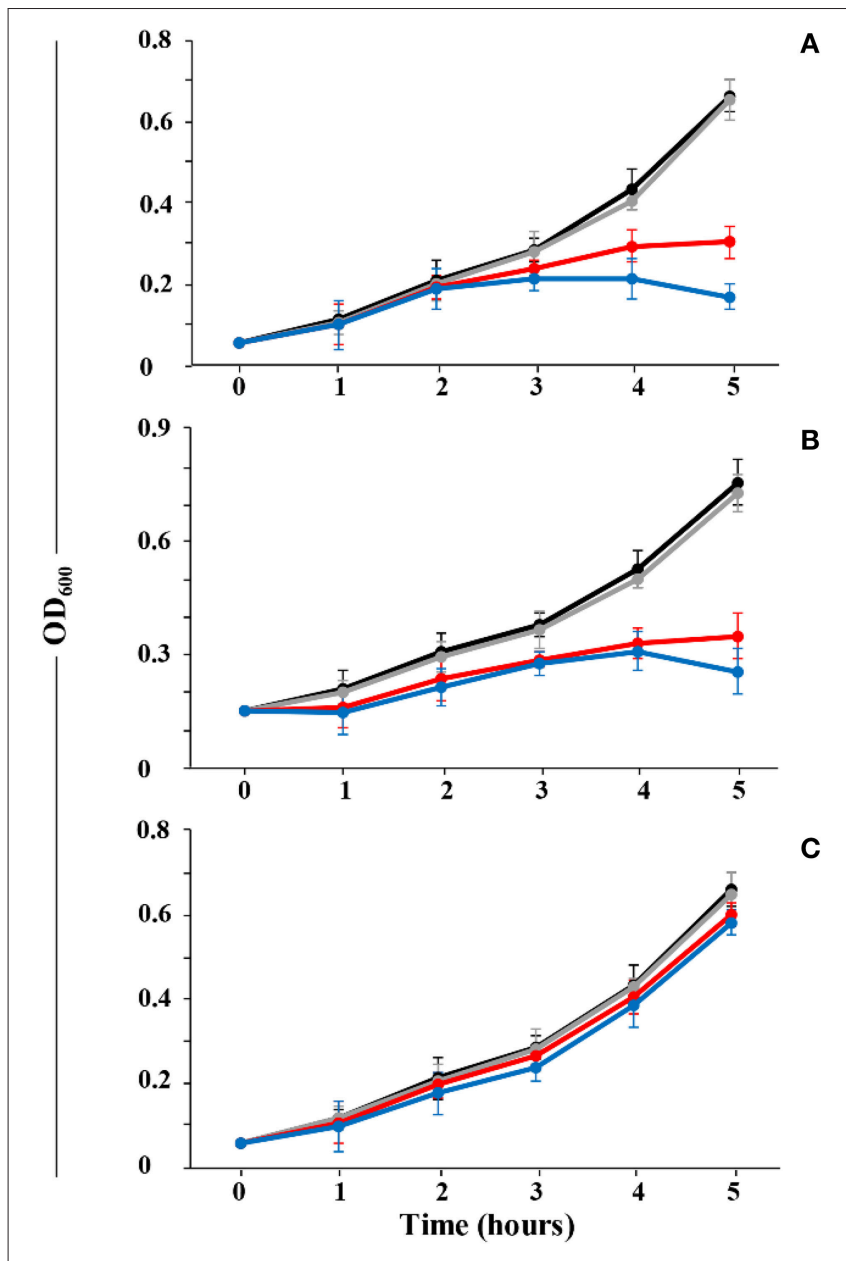

FIGURE 7 | Sequential activity of thusin peptides against $B$.

thuringiensis BMB171. (A) Ths $\alpha$ and Ths $\beta$ simultaneously added. (B) Ths $\alpha$ followed by Ths $\beta$ addition. (C) Ths $\beta$ followed by Ths $\alpha$ addition. Different concentrations are displayed as black $(0 \mathrm{nM})$, gray $(10 \mathrm{nM})$, red $(30 \mathrm{nM})$, and blue $(60 \mathrm{nM})$ lines. The means and standard deviations are presented.

thusin could inhibit the outgrowth of $B$. cereus spores when the concentration reached $0.39 \mu \mathrm{M}$ (Figure 8). In addition, Ths $\alpha$, Ths $\beta$ and Ths $\beta$ ' could also inhibit the outgrowth of spores when the concentration was greater than $6.25 \mu \mathrm{M}, 12.5 \mu \mathrm{M}$ and $12.5 \mu \mathrm{M}$, respectively (data not shown). Therefore, Ths $\alpha$ and Ths $\beta$ (or Ths $\beta$ ') could synergistically inhibit the outgrowth of B. cereus spores.

\section{DISCUSSION}

The increasing incidence of drug-resistant pathogens has prompted the pharmaceutical and scientific communities to investigate alternatives to traditional antibiotics, such as bacteriocins. Bacteriocins exhibit several desirable properties that make them suitable as alternatives to traditional antibiotics: (i) they are potent (in vitro and in vivo), (ii) they are minimally toxic, (iii) they can be produced in situ by probiotics, and (iv) they are amenable to bioengineering (Cotter et al., 2013). A subgroup of bacteriocins, lantibiotics, especially two-component lantibiotics, exhibit potent antimicrobial activity against clinically relevant pathogens, including multidrug-resistant strains, and they are being extensively researched as a potential new source of antimicrobials to treat infections (Cotter et al., 2013; Dischinger et al., 2014; Sandiford, 2014). Given the high potency and potential clinical applications of two-component lantibiotics, this study aimed to mine novel two-component lantibiotics that exhibit excellent properties, especially in terms of antibacterial activity against bacterial pathogens in the $B$. cereus group. Finally, we identified and characterized one type of novel twocomponent lantibiotic, the thusin gene cluster in B. thuringiensis strain BGSC 4BT1. The mature peptides, Ths $\alpha$ and Ths $\beta$ (or Ths $\beta^{\prime}$ ), act synergistically to potently inhibit several Grampositive pathogens, including B. cereus, L. monocytogenes, Staph. aureus (MRSA), Staph. sciuri, E. faecalis, and Strep. pneumoniae. To our knowledge, thusin is the first reported two-component lantibiotic in the $B$. cereus group and has potential applications in the pharmaceutical industry.

The optimal ratio of Ths $\alpha$ to Ths $\beta$ (or Ths $\beta$ ') that maximized bioactivity was 1:1. Due to the differences in the maximum absorption wavelengths of Ths $\alpha$ and Ths $\beta$, the absorption peak areas of Ths $\alpha$, Ths $\beta$ and Ths $\beta$ ' at $220 \mathrm{~nm}$ differed (Figure 2), but the number of moles of the compounds was $\sim 2: 1: 1$ (data not shown). Although the three structural genes shared one promoter, the transcription of ths 11 likely exceeded that of ths $A 2$ and ths $A 2^{\prime}$. Consequently, the yields of Ths $\alpha$, Ths $\beta$ and Ths $\beta$ ' were close to the optimal ratio to maximize the effect on cells.

In our previous study, we identified two single-component lantibiotics, thurisin 4A-4, and ticin from B. thuringiensis T01001 and BMB3201, respectively (Xin et al., 2015a,b). We found that the cell-free supernatants of $B$. thuringiensis T01001, BMB3201, and BGSC 4BT1 exhibited comparable antimicrobial activity against most of the tested Gram-positive strains (data not shown). The production of thurisin $4 \mathrm{~A}-4$ and ticin were both $\sim 1 \mathrm{mM} / \mathrm{L}$, but thusin was only 0.1 to $0.2 \mathrm{mM} / \mathrm{L}$. Comparison of antimicrobial activity between thusin, thuricin 4A-4, and ticin A4 showed that thusin had higher activity against all tested indicator bacteria (Figure 5). Therefore, the antimicrobials produced by B. thuringiensis BGSC 4BT1 was less than those from two other strains but played a comparable activity. This result indicated that the production of two-component lantibiotics was more effective than the production of single-component lantibiotics based on the survival and adaptability of the producer strains in various ecological environments. Another way, the low yield of thusin will not be conducive to its future application, and we will take some genetic engineering strategies to improve the production of thusin in further research. For example, overexpression of thusin self-protection genes in the producer strain (Heinzmann et al., 2006).

Comparison of antibacterial activity between thusin and vancomycin demonstrated that thusin had a higher activity against all tested Gram-positive pathogens. The glycopeptide antibiotic vancomycin was introduced clinically nearly 60 years ago and has been widely used to treat severe infections due to Gram-positive bacteria resistant to $\beta$-lactam antibiotics, in particular the infection caused by methicillin-resistant 


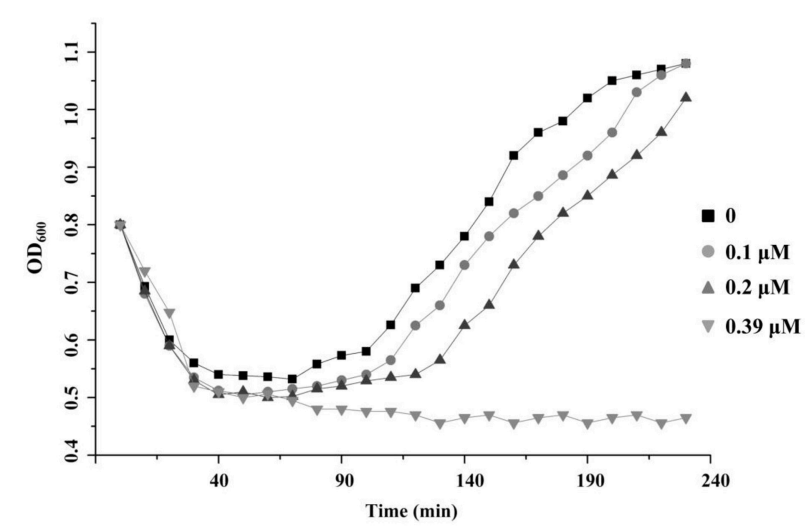

FIGURE 8 | Inhibition of Bacillus cereus spore outgrowth by thusin. The germination process of $B$. cereus ATCC14579 spores was monitored by measuring the optical density at $600 \mathrm{~nm}$ every $10 \mathrm{~min}$.

S. aureus (MRSA) (Mainardi et al., 2008). However, the emergence of vancomycin-resistant enterococci (VRE) and vancomycin-resistant staphylococci attenuated its application in recent years (Leclercq et al., 1988; Uttley et al., 1988; Centers for Disease Control and Prevention, 1997; Chang et al., 2003; Courvalin, 2006). In addition, thusin also showed higher activity against all tested indicator bacteria than thuricin A4 and Ticin A4. These results suggested that thusin had obvious advantages in terms of antimicrobial activity, and also indicated the potential for its use as an alternative to conventional antibiotics against the infections caused by Gram-positive pathogens.

Lipid II has been identified as the target molecule of a number of lantibiotics, such as mersacidin. The $\mathrm{C}$ ring of mersacidin can bind to lipid II and inhibit transglycosylation in a $\mathrm{Ca}^{2+}$-dependent manner, and this structure is conserved in other class II lantibiotics (Brötz et al., 1998; Hsu et al., 2003; Knerr and Van der Donk, 2012), including Ths $\alpha$. Recent studies have revealed the mode of action of the two-component lantibiotics lacticin 3147 and haloduracin: the $\alpha$-peptide first interacts specifically with lipid II and the lipid II: $\alpha$-peptide complex is then able to recruit the $\beta$-peptide to form an active three-component complex and subsequently inhibit cell wall biosynthesis to form small pores in the cell membrane (Morgan et al., 2005; Wiedemann et al., 2006; Oman and Van der Donk, 2009). We found that Ths $\alpha$ and Ths $\beta$ acted sequentially to affect the sensitive strain $B$. thuringiensis BMB171, and this phenomenon was identical to that observed for the two-component lantibiotics lacticin 3147 and haloduracin. We speculated that Ths $\alpha$ binds the cell wall precursor lipid II, and the lipid II:Ths $\alpha$ complex is required for Ths $\beta$ to exert its synergistic

\section{REFERENCES}

Andersson, D. I., and Hughes, D. (2010). Antibiotic resistance and its cost: is it possible to reverse resistance? Nat. Rev. Microbiol. 8, 260-271. doi: $10.1038 /$ nrmicro2319 effect to inhibit cell wall biosynthesis and form pores in the cell membrane. We will test this hypothesis in future studies.

B. cereus is a human pathogen that causes diarrheal or emetic-type illnesses (Ramarao and Sanchis, 2013). Its highly resistant spores can survive in food processing treatments and can be present in final products, where they may lead to food spoilage and food-borne illness (Warda et al., 2015). Previous studies have shown that some lantibiotics are able to inhibit the outgrowth of Bacillus spores (Liu and Hansen, 1993; Oman and Van der Donk, 2009; Gut et al., 2011). In this study, we revealed that the components of thusin synergistically prevented the outgrowth of $B$. cereus spores. To date, only the molecular basis by which nisin inhibits spore outgrowth has been extensively studied. Specifically, nisin utilizes lipid II as the germinated spore target during outgrowth inhibition and causes membrane disruption (Liu and Hansen, 1993; Gut et al., 2011). The mechanism by which two-component lantibiotics such as thusin prevent the outgrowth of $B$. cereus spores may differ from that of the single-component lantibiotic nisin; we will investigate this mechanism in future studies. However, the ability of thusin to inhibit the outgrowth of $B$. cereus spores demonstrates its potential application in the food industry.

Finally, we have to emphasize that the systematic safety testing of thusin and its antimicrobial activity in vivo are crucial for its successful application as a new drug or food additive. We have determined that thusin $(>1 \mathrm{mg} / \mathrm{mL}$ ) had no hemolytic activity (data not shown), and more detailed testing will be performed to assess the feasibility of its application in further study.

\section{AUTHOR CONTRIBUTIONS}

$\mathrm{BX}$, JZ, and MS designed research; BX, HL, JL, and MSa performed research; BX, JZ, LR, DP, and MS analyzed data; BX and MS wrote the paper.

\section{ACKNOWLEDGMENTS}

This work was supported by grants from the China 948 Program of the Ministry of Agriculture (2016-X21 and 2011-G25), the National High Technology Research and Development Program (863) of China (2011AA10A203), the National Natural Science Foundation of China (31500003, 31270137, and 31171901), and Huazhong Agricultural University Independent Scientific \& Technological Innovation Foundation.

\section{SUPPLEMENTARY MATERIAL}

The Supplementary Material for this article can be found online at: http://journal.frontiersin.org/article/10.3389/fmicb. 2016.01115
Assadian, O., Wehse, K., Hübner, N. O., Koburger, T., Bagel, S., Jethon, F., et al. (2011). Minimum inhibitory (MIC) and minimum microbicidal concentration (MMC) of polihexanide and triclosan against antibiotic sensitive and resistant Staphylococcus aureus and Escherichia coli strains. GMS Krankenhhyg. Interdiszip. 6:Doc06. doi: 10.3205/dgkh000163 
Begley, M., Cotter, P. D., Hill, C., and Ross, R. P. (2009). Identification of a novel two-peptide lantibiotic, lichenicidin, following rational genome mining for LanM proteins. Appl. Environ. Microbiol. 75, 5451-5460. doi: 10.1128/AEM.00730-09

Brötz, H., Bierbaum, G., Leopold, K., Reynolds, P. E., and Sahl, H. G. (1998). The lantibiotic mersacidin inhibits peptidoglycan synthesis by targeting lipid II. Antimicrob. Agents. Chemother. 42, 154-160.

Brown, E. D., and Wright, G. D. (2016). Antibacterial drug discovery in the resistance era. Nature 529, 336-343. doi: 10.1038/nature17042

Burrowes, B., Harper, D. R., Anderson, J., Mcconville, M., and Enright, M. C. (2011). Bacteriophage therapy: potential uses in the control of antibiotic-resistant pathogens. Expert Rev. Anti. Infect. Ther. 9, 775-785. doi: 10.1586/eri.11.90

Carroll, J., Draper, L. A., O'connor, P. M., Coffey, A., Hill, C., Ross, R. P., et al. (2010). Comparison of the activities of the lantibiotics nisin and lacticin 3147 against clinically significant mycobacteria. Int. J. Antimicrob. Agents 36, 132-136. doi: 10.1016/j.ijantimicag.2010.03.029

Centers for Disease Control and Prevention (1997). Reduced susceptibility of Staphylococcus aureus to vancomycin-Japan, 1996. MMWR Morb. Mortal. Wkly. Rep. 46, 624-626.

Chang, S., Sievert, D. M., Hageman, J. C., Boulton, M. L., Tenover, F. C., Downes, F. P., et al. (2003). Infection with vancomycin-resistant Staphylococcus aureus containing the vanA resistance gene. N. Engl. J. Med. 348, 1342-1347. doi: 10.1056/NEJMoa025025

Cotter, P. D., Hill, C., and Ross, R. P. (2005). Bacteriocins: developing innate immunity for food. Nat. Rev. Microbiol. 3, 777-788. doi: 10.1038/nrmicro1273

Cotter, P. D., Ross, R. P., and Hill, C. (2013). Bacteriocins - a viable alternative to antibiotics? Nat. Rev. Microbiol. 11, 95-105. doi: 10.1038/nrmicr o2937

Courvalin, P. (2006). Vancomycin resistance in gram-positive cocci. Clin. Infect. Dis. 42(Suppl. 1), S25-S34. doi: 10.1086/491711

Deng, Y., Zhu, Y., Wang, P., Zhu, L., Zheng, J., Li, R., et al. (2011). Complete genome sequence of Bacillus subtilis BSn5, an endophytic bacterium of Amorphophallus konjac with antimicrobial activity for the plant pathogen Erwinia carotovora subsp. carotovora. J. Bacteriol. 193, 2070-2071. doi: 10.1128/JB.00129-11

Dischinger, J., Basi Chipalu, S., and Bierbaum, G. (2014). Lantibiotics: promising candidates for future applications in health care. Int. J. Med. Microbiol. 304, 51-62. doi: 10.1016/j.ijmm.2013.09.003

Dobson, A., O'connor, P. M., Cotter, P. D., Ross, R. P., and Hill, C. (2011). Impact of the broad-spectrum antimicrobial peptide, lacticin 3147, on Streptococcus mutans growing in a biofilm and in human saliva. J. Appl. Microbiol. 111, 1515-1523. doi: 10.1111/j.1365-2672.2011.05153.x

Galvin, M., Hill, C., and Ross, R. P. (1999). Lacticin 3147 displays activity in buffer against gram-positive bacterial pathogens which appear insensitive in standard plate assays. Lett. Appl. Microbiol. 28, 355-358. doi: 10.1046/j.13652672.1999.00550.x

Garneau, S., Martin, N. I., and Vederas, J. C. (2002). Two-peptide bacteriocins produced by lactic acid bacteria. Biochimie 84, 577-592. doi: 10.1016/S03009084(02)01414-1

Gut, I. M., Blanke, S. R., and Van der Donk, W. A. (2011). Mechanism of inhibition of Bacillus anthracis spore outgrowth by the lantibiotic nisin. ACS Chem. Biol. 6, 744-752. doi: 10.1021/cb1004178

Heinzmann, S., Entian, K. D., and Stein, T. (2006). Engineering Bacillus subtilis ATCC 6633 for improved production of the lantibiotic subtilin. Appl. Microbiol. Biot. 69, 532-536. doi: 10.1007/s00253-005-0023-9

Holo, H., Jeknic, Z., Daeschel, M., Stevanovic, S., and Nes, I. F. (2001). Plantaricin W from Lactobacillus plantarum belongs to a new family of two-peptide lantibiotics. Microbiology 147, 643-651. doi: 10.1099/00221287-147-3-643

Hornstra, L. M., De Vries, Y. P., De Vos, W. M., Abee, T., and Wells-Bennik, M. H. (2005). gerR, a novel ger operon involved in L-alanine- and inosineinitiated germination of Bacillus cereus ATCC 14579. Appl. Environ. Microbiol. 71, 774-781. doi: 10.1128/AEM.71.2.774-781.2005

Hsu, S. T., Breukink, E., Bierbaum, G., Sahl, H. G., De Kruijff, B., Kaptein, R., et al. (2003). NMR study of mersacidin and lipid II interaction in dodecylphosphocholine micelles. Conformational changes are a key to antimicrobial activity. J. Biol. Chem. 278, 13110-13117. doi: 10.1074/jbc.M211144200
Hyink, O., Balakrishnan, M., and Tagg, J. R. (2005). Streptococcus rattus strain BHT produces both a class I two-component lantibiotic and a class II bacteriocin. FEMS Microbiol. Lett. 252, 235-241. doi: 10.1016/j.femsle.2005.09.003

Knerr, P. J., and Van der Donk, W. A. (2012). Discovery, biosynthesis, and engineering of lantipeptides. Annu. Rev. Biochem. 81, 479-505. doi: 10.1146/annurev-biochem-060110-113521

Kole, R., Krainer, A. R., and Altman, S. (2012). RNA therapeutics: beyond RNA interference and antisense oligonucleotides. Nat. Rev. Drug Discov. 11, 125-140. doi: $10.1038 / \mathrm{nrd} 3625$

Leclercq, R., Derlot, E., Duval, J., and Courvalin, P. (1988). Plasmid-mediated resistance to vancomycin and teicoplanin in Enterococcus faecium. N. Engl. J. Med. 319, 157-161. doi: 10.1056/NEJM198807213190307

Li, Y., Xiang, Q., Zhang, Q., Huang, Y., and Su, Z. (2012). Overview on the recent study of antimicrobial peptides: origins, functions, relative mechanisms and application. Peptides 37, 207-215. doi: 10.1016/j.peptides.2012.07.001

Liu, W., and Hansen, J. N. (1993). The antimicrobial effect of a structural variant of subtilin against outgrowing Bacillus cereus $\mathrm{T}$ spores and vegetative cells occurs by different mechanisms. Appl. Environ. Microbiol. 59, 648-651.

Mainardi, J. L., Villet, R., Bugg, T. D., Mayer, C., and Arthur, M. (2008). Evolution of peptidoglycan biosynthesis under the selective pressure of antibiotics in Gram-positive bacteria. FEMS Microbiol. Rev. 32, 386-408. doi: 10.1111/j.15746976.2007.00097.x

McClerren, A. L., Cooper, L. E., Quan, C., Thomas, P. M., Kelleher, N. L., and Van der Donk, W. A. (2006). Discovery and in vitro biosynthesis of haloduracin, a two-component lantibiotic. Proc. Natl. Acad. Sci. U.S.A. 103, 17243-17248. doi: 10.1073/pnas.0606088103

Morgan, S. M., O'connor, P., M., Cotter, P. D., Ross, R. P., and Hill, C. (2005). Sequential actions of the two component peptides of the lantibiotic lacticin 3147 explain its antimicrobial activity at nanomolar concentrations. Antimicrob. Agents Chemother. 49, 2606-2611. doi: 10.1128/AAC.49.7.2606-2611.2005

Navaratna, M. A., Sahl, H. G., and Tagg, J. R. (1998). Two-component antiStaphylococcus aureus lantibiotic activity produced by Staphylococcus aureus C55. Appl. Environ. Microbiol. 64, 4803-4808.

Oman, T. J., and Van der Donk, W. A. (2009). Insights into the mode of action of the two-peptide lantibiotic haloduracin. ACS Chem. Biol. 4, 865-874. doi: $10.1021 / \mathrm{cb} 900194 \mathrm{x}$

Piper, C., Casey, P. G., Hill, C., Cotter, P. D., and Ross, R. P. (2012). The lantibiotic lacticin 3147 prevents systemic spread of Staphylococcus aureus in a murine infection model. Int. J. Microbiol. 2012:806230. doi: 10.1155/2012/806230

Ramarao, N., and Sanchis, V. (2013). The pore-forming haemolysins of Bacillus cereus: a review. Toxins 5, 1119-1139. doi: 10.3390/toxins5061119

Rea, M. C., Clayton, E., O'connor, P. M., Shanahan, F., Kiely, B., Ross, R. P., et al. (2007). Antimicrobial activity of lacticin 3,147 against clinical Clostridium difficile strains. J. Med. Microbiol. 56, 940-946. doi: 10.1099/jmm.0.47085-0

Ryan, M. P., Jack, R. W., Josten, M., Sahl, H. G., Jung, G., Ross, R. P., et al. (1999). Extensive post-translational modification, including serine to D-alanine conversion, in the two-component lantibiotic, lacticin 3147. J. Biol. Chem. 274, 37544-37550. doi: 10.1074/jbc.274.53.37544

Sandiford, S. K. (2014). Advances in the arsenal of tools available enabling the discovery of novel lantibiotics with therapeutic potential. Expert Opin. Drug Discov. 9, 283-297. doi: 10.1517/17460441.2014.877882

Savoia, D. (2012). Plant-derived antimicrobial compounds: alternatives to antibiotics. Future Microbiol. 7, 979-990. doi: 10.2217/fmb.12.68

Sawa, N., Wilaipun, P., Kinoshita, S., Zendo, T., Leelawatcharamas, V., Nakayama, J., et al. (2012). Isolation and characterization of enterocin W, a novel twopeptide lantibiotic produced by Enterococcus faecalis NKR-4-1. Appl. Environ. Microbiol. 78, 900-903. doi: 10.1128/AEM.06497-11

Schnell, N., Entian, K. D., Schneider, U., Götz, F., Zähner, H., Kellner, R., et al. (1988). Prepeptide sequence of epidermin, a ribosomally synthesized antibiotic with four sulphide-rings. Nature 333, 276-278. doi: 10.1038/333276a0

Severina, E., Severin, A., and Tomasz, A. (1998). Antibacterial efficacy of nisin against multidrug-resistant Gram-positive pathogens. J. Antimicrob. Chemother. 41, 341-347. doi: 10.1093/jac/41.3.341

Shanahan, F. (2010). Probiotics in perspective. Gastroenterology 139, 1808-1812. doi: 10.1053/j.gastro.2010.10.025

Shenkarev, Z. O., Finkina, E. I., Nurmukhamedova, E. K., Balandin, S. V., Mineev, K. S., Nadezhdin, K. D., et al. (2010). Isolation, structure elucidation, and synergistic antibacterial activity of a novel two-component lantibiotic 
lichenicidin from Bacillus licheniformis VK21. Biochemistry 49, 6462-6472. doi: 10.1021/bi100871b

Uttley, A. H., Collins, C. H., Naidoo, J., and George, R. C. (1988). Vancomycinresistant enterococci. Lancet 1, 57-58. doi: 10.1016/S0140-6736(88)91037-9

Van Heel, A. J., De Jong, A., Montalbán-López, M., Kok, J., and Kuipers, O. P. (2013). BAGEL3: automated identification of genes encoding bacteriocins and (non-)bactericidal posttranslationally modified peptides. Nucleic Acids Res. 41, W448-W453. doi: 10.1093/nar/gkt391

Warda, A. K., Den Besten, H. M., Sha, N., Abee, T., and Nierop Groot, M. N. (2015). Influence of food matrix on outgrowth heterogeneity of heat damaged Bacillus cereus spores. Int. J. Food Microbiol. 201, 27-34. doi: 10.1016/j.ijfoodmicro.2015.02.010

Wiedemann, I., Böttiger, T., Bonelli, R. R., Wiese, A., Hagge, S. O., Gutsmann, T., et al. (2006). The mode of action of the lantibiotic lacticin 3147-a complex mechanism involving specific interaction of two peptides and the cell wall precursor lipid II. Mol. Microbiol. 61, 285-296. doi: 10.1111/j.13652958.2006.05223.x

Willey, J. M., and Van der Donk, W. A. (2007). Lantibiotics: peptides of diverse structure and function. Annu. Rev. Microbiol. 61, 477-501. doi: 10.1146/annurev.micro.61.080706.093501

Wu, Y., Zheng, J., Wang, Y., Li, S., Jin, H., Li, Z., et al. (2015). Draft genome sequence of Listeria monocytogenes LM201, isolated from foodstuff. Genome Announc. 3, e01417-e01414. doi: 10.1128/genomeA.01417-14
Xin, B., Zheng, J., Xu, Z., Li, C., Ruan, L., Peng, D., et al. (2015a). Three novel lantibiotics, ticins $\mathrm{A} 1, \mathrm{~A} 3$, and A4, have extremely stable properties and are promising food biopreservatives. Appl. Environ. Microbiol. 81, 6964-6972. doi: 10.1128/AEM.01851-15

Xin, B., Zheng, J., Xu, Z., Song, X., Ruan, L., Peng, D., et al. (2015b). The Bacillus cereus group is an excellent reservoir of novel lanthipeptides. Appl. Environ. Microbiol. 81, 1765-1774. doi: 10.1128/AEM.037 58-14

Yonezawa, H., and Kuramitsu, H. K. (2005). Genetic analysis of a unique bacteriocin, Smb, produced by Streptococcus mutans GS5. Antimicrob. Agents Chemother. 49, 541-548. doi: 10.1128/AAC.49.2.541-548.2005

Conflict of Interest Statement: The authors declare that the research was conducted in the absence of any commercial or financial relationships that could be construed as a potential conflict of interest.

Copyright $\odot 2016$ Xin, Zheng, Liu, Li, Ruan, Peng, Sajid and Sun. This is an openaccess article distributed under the terms of the Creative Commons Attribution License (CC BY). The use, distribution or reproduction in other forums is permitted, provided the original author(s) or licensor are credited and that the original publication in this journal is cited, in accordance with accepted academic practice. No use, distribution or reproduction is permitted which does not comply with these terms. 